\title{
TRICHOMES OF CANNABIS SATIVA L. (CANNABACEAE) ${ }^{1}$
}

\author{
P. Dayanandan and Peter B. Kaufman \\ Department of Botany, University of Michigan, Ann Arbor 48104
}

A B S T R A C T

The diversity of non-glandular and glandular hairs of Cannabis sativa $\mathbf{L}$. (marihuana) are described by scanning electron microscopy. The non-glandular hairs are of two major types, as distinguished by size differences and locations, and all of them are highly silicified. The presence of silica as well as cystoliths of calcium carbonate help in the identification of marihuana even in its ash residues. X-ray microanalyses of Cannabis hairs are compared with those of Humulus lupulus and Lantana camera, whose hairs have been considered to resemble those of marihuana. Glandular hairs are found to be of two major categories. One group consists of glands whose heads are generally made up of eight cells and the other group whose heads are generally made up of two cells but never more than four cells. All glands of both categories are stalked. Some glands of the first category are massively stalked and these are restricted solely to anthers and bracts of staminate and pistillate plants. The massive stalk is considered to be made up of epidermal and hypodermal cells that have grown in response to some stimulation during anthesis. Fine details of the shoot system of Cannabis, such as cuticular ridges on epidermal cells, warty protuberances on non-glandular hairs, and surface views of glands in developing stages are also reported. Glandular hairs on the bracts of Humulus lupulus resemble those of Cannabis.

MOST OF THE AERIAL parts of Cannabis sativa $\mathrm{L}$ (the Indian hemp plant or marihuana) are covered with different types of non-glandular and glandular trichomes. In spite of its importance as an economic plant of antiquity, the botany of Cannabis is still poorly understood (Schultes, 1970; Schultes et al., 1974). This applies particularly to the nature of glandular hairs which are considered to be the primary locations of the narcotic cannabinoids. Briosi and Tognini $(1894,1897)$ presented a detailed description and illustrations of the various trichomes of Cannabis and also summarized previous works on Cannabis sativa. Besides Mohan Ram and Nath's (1964) cursory reference to the ontogeny of the trichomes, most

${ }^{1}$ Received for publication 7 April 1975.

The authors wish to thank Dr. Erich Steiner, Director, University of Michigan Matthaei Botanical Gardens for the supply of specimens, and Dr. W. C. Bigelow and his staff for use of the scanning electron microscope facilities. We also thank Diane Hoefle, Frederick Hebard, David Bay, and William Stein for their encouragement and assistance. This work was supported in part by NSF grant BMS 75-16359. workers have described some aspects of the mature trichomes only (Ballard and Phar, 1915; Bouquet, 1950; Shimomura et al., 1967; Jackson and Snowdon, 1968). Recently, the need for the identification of marihuana in illicit trade and possession has resulted in several publications, forensic in nature, which mostly describe the nonglandular cystolith hairs. These studies have employed either the light microscope (Asahina et al., 1967; Shimomura et al., 1967; Nakamura, 1969; Nordal, 1970; Thornton and Nakamura, 1972; De Forest, Morton and Henderson, 1974) or the scanning electron microscope (Bradford and Devaney, 1970; Devaney and Bradford, 1971; Siegesmund and Hunter, 1971; Mitosinka, Thornton and Hayes, 1972). Such studies on the iden-. tification of marihuana have been carried out on resin, dried leaves or ash residues of Cannabis as well as on the dried leaves of nearly 90 different plants that are said to possess cystolith hairs that could be confused with those of Cannabis.

Hammond and Mahlberg (1973) made use of the scanning electron microscope to describe three

Fig. 1-7. Surface features of regions of shoot system of Cannabis sativa. All figures obtained from fresh, live specimens without any treatment. 1. A lobe of a young leaflet with reduced stomata near the tip, and several nonglandular trichomes. $\times 265$. 2. Adaxial surface of a young leaf with cystolith trichomes of two sizes and a few bulbous glands. Some trichome initials are seen in the groove. $\times 260$. 3. Mature region of a leaflet tip showing cuticular ridges and reduced stomata. $\times 265$. 4. Surface of petiole showing non-glandular hairs, several capitate glands and a few bulbous glands. $\times 85$. 5. Abaxial leaf surface with trichomes and stomata. Hairs are devoid of warty projections. Three capitate glands are seen to the left and two bulbous glands to the right. $\times 250$. 6 . Adaxial leaf surface. Cuticular ridges on the epidermis a re yet to develop. $\times 250$. 7 . Adaxial leaf surface showing a capitate gland, long and short cystolith trichomes, and a ring of cells surrounding the long hair. $\times 250$. 


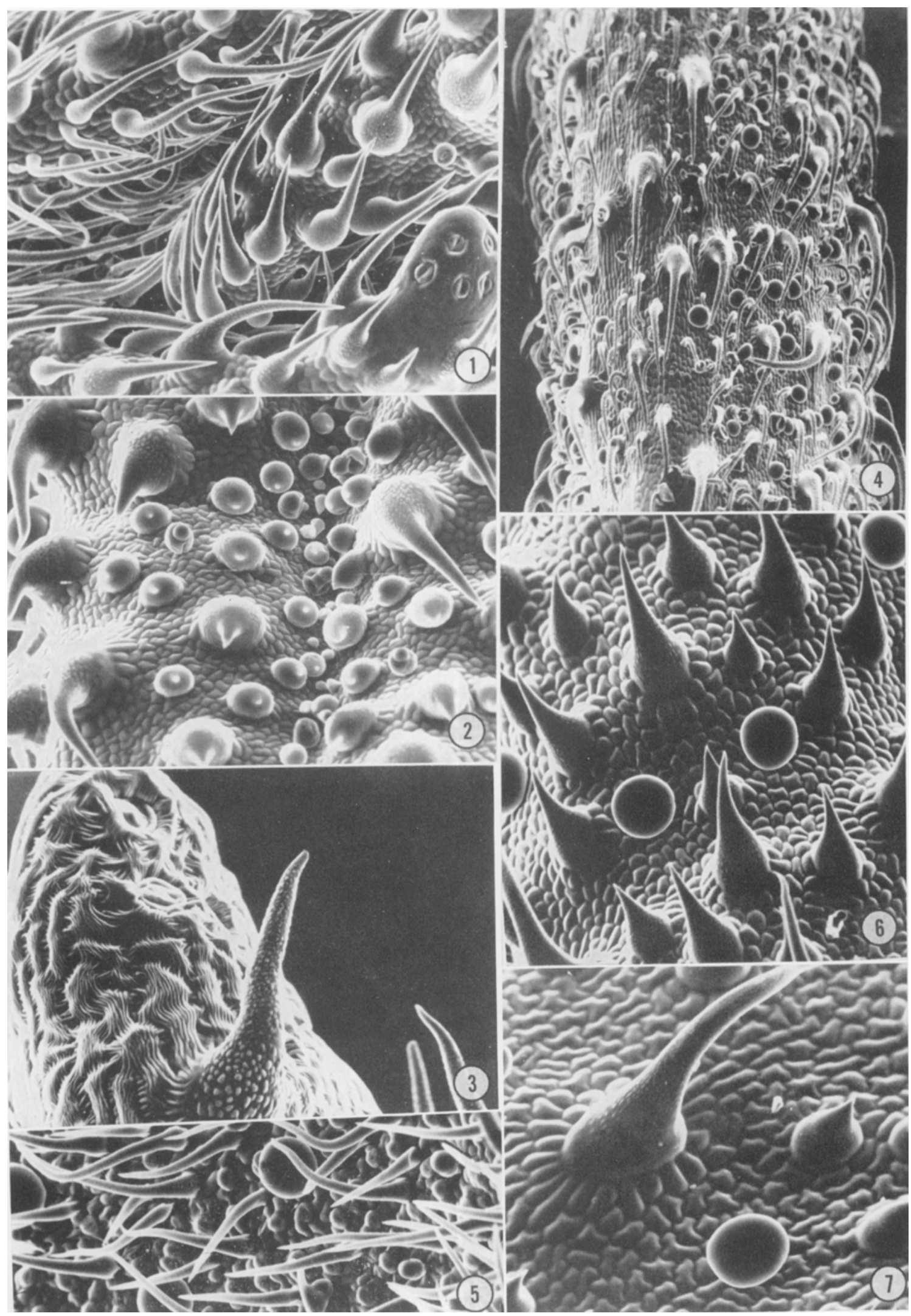




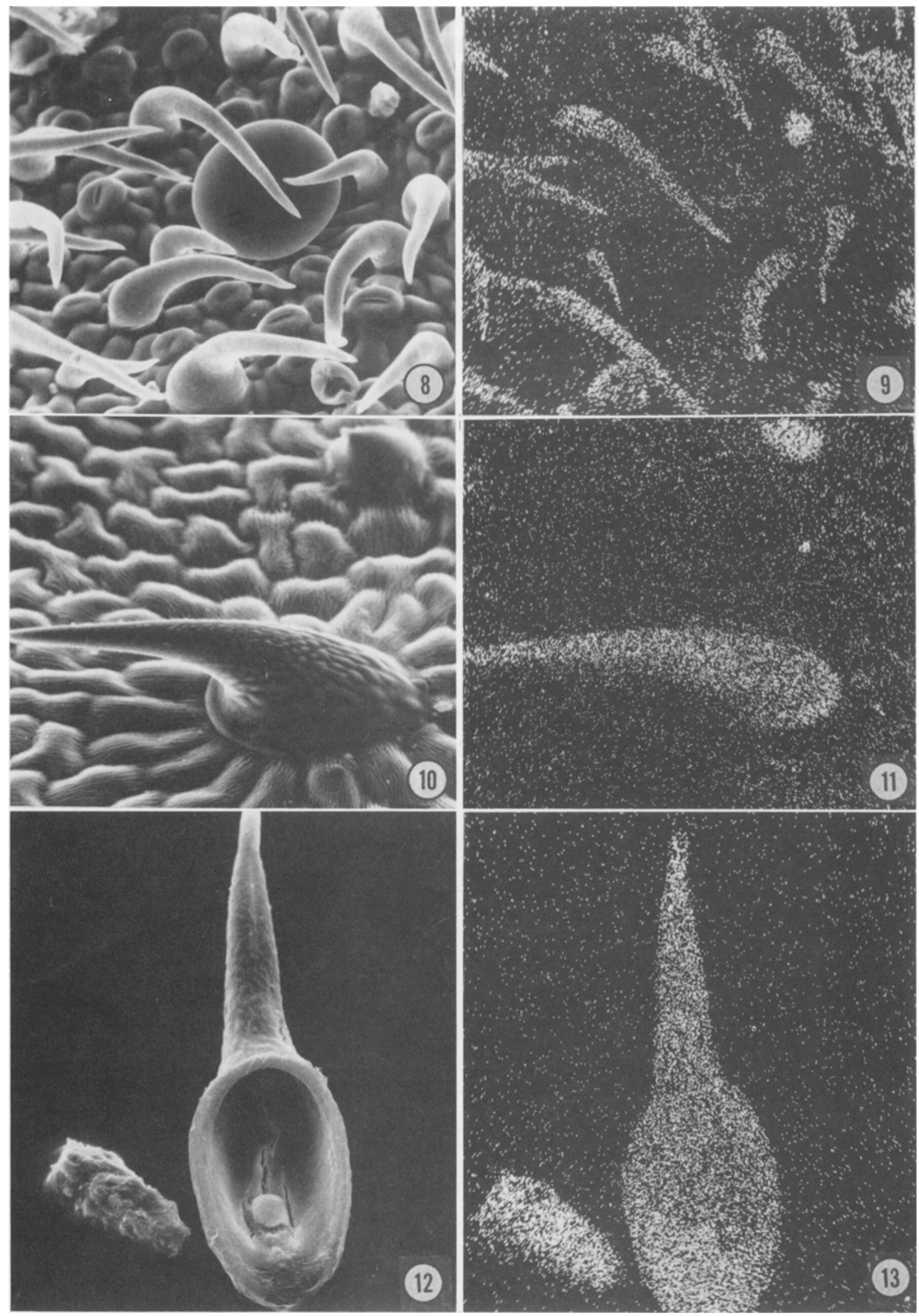


types of glandular hairs that occur on the pistillate plants, especially on the flowering bracts. In this paper, we extend this study to the shoots of staminate plants which bear as many different types of glandular hairs as the pistillate plants. Using an X-ray detecting system that is coupled to the scanning electron microscope, we also analyse the pattern of silicification and calcification in the nonglandular hairs of Cannabis sativa, Humulus lupulus (hops, the only other genus in Cannabaceae) and Lantana camera (Verbenaceae). X-ray microanalysis data on the above plants, as well as on burnt ash residues of marihuana, provide information of taxonomic value that make identification of marihuana more definitive. Because of the variation that exists among the trichomes of $\mathrm{Can}$ nabis, their study should lead to a better understanding of the real taxonomic relations that exist between widely different forms of Cannabis that have usually been grouped under one species, $C$. sativa (Schultes et al., 1974). Marihuana contains about 20 different cannabinoids, including tetrahydrocannabinol, the major hallucinogenic component. The study of Cannabis glands is also essential to understand the biogenesis, distribution and function of the different cannabinoids.

Materials AND METHODS-A pistillate and a staminate plant of Cannabis which have been growing in the University of Michigan Matthaei Botanical Gardens were used for most of the investigation. A few seedlings from the Botanical Gardens were also employed to study the differentiation of trichomes during early stages of growth of Cannabis. The plants employed fit the usual description of typical Cannabis sativa (Schultes et al., 1974).

Most of the scanning electron microscopic (SEM) studies were done with fresh specimens. Small segments were mounted on aluminum stubs with carbon paint and examined immediately in the SEM (JEOL model JSM-U3). At an accelerating voltage of $15 \mathrm{KeV}$, fresh specimens could be examined for about 20 min without much damage to them. X-ray microanalyses were also done mostly on fresh specimens by coupling to the SEM an X-ray detector and amplifier system (KEVEX) and a multichannel analyser (Northern Scientific, Model 710). Selected areas of the specimen were first photographed in the secondary emission mode followed by X-ray mapping for calcium and/or silicon. This order was nec- essary because beam or vacuum damage to the specimen was increased with the longer exposure times that were used for X-ray analysis.

Samples were also subjected to critical-point drying in order to compare the structures with fresh sample preparations. Materials were fixed in FAA, dehydrated in ethanol and critical-point dried with liquid $\mathrm{CO}_{2}$ as an intermediate. Preparations thus obtained were as good as those that employed amyl acetate instead of ethanol. Critical-point dried samples of Cannabis, as well as air dried samples of Humulus lupulus and Lantana camera (both obtained from the Matthaei Botanical Gardens) were coated with a thin layer of gold before examining them in the SEM.

Ash residues were obtained from dried leaves and flowering tops of pistillate and staminate plants of Cannabis. A marihuana cigarette was attached to an aspirator through glass and rubber tubings and the ash falling from the lit end was collected on clean pieces of aluminum foil. Small quantities of the finest ash samples were spread on scotch tapes and mounted on aluminum stubs to be gold-coated and examined with the SEM.

Fresh samples of Cannabis leaves that show minimal damage during examination with the SEM are better suited for X-ray microanalysis than dried and gold-coated samples. However, in Cannabis, Humulus, Lantana, and ash residues of Cannabis, silica and calcium deposition occur in such large quantities that no interference is encountered even with gold-coated samples during qualitative X-ray analysis for these elements.

While this study focuses on SEM aspects of the trichomes of Cannabis, conventional microtechnical methods (microtome sections, acid-hydrolysed squash preparations) were also employed to corroborate findings obtained with the SEM.

OBSERVATIONS-Non-glandular hairs-The stems, petioles, stipules, leaf blades, bracts, and both surfaces of the tepals are all covered with hairs that are strictly unicellular (Fig. 1-7, 30, 31 ). Figure 1 depicts a young leaf which shows stages in the development of hairs. The tip of a leaflet possesses 6-15 stomata, probably modified to function as hydathodes. Immediately below the tip are well-developed and elongating trichomes. Warty protuberances characteristic of these trichomes are already visible (Fig. 1-3). At a still lower level, hair initials are seen among fully differentiated hairs. Such an admixture of

$\leftarrow$

Fig. 8-13. Secondary and X-ray images of silicon of non-glandular hairs of Cannabis.-Fig. 8-11. Fresh, live specimens without any treatment. 8, 9. Abaxial leaf surface. Note silicon localization only on hairs and also on a contaminant, perhaps a soil particle. $\times 500.10,11$. Two kinds of trichomes from adaxial leaf surface. Silicon is localized in both types. $\times 520 .-$ Fig. 12,13 . Trichome macerated in conc. nitric and chromic acid mixture, air dried and gold-coated. 12, 13. Isolated hair from the adaxial leaf surface. The cystolith of $\mathrm{CaCO}_{3}$ has been removed but the region where it was attached still remains. Also seen is a broken piece of another hair. $\times 950$. 


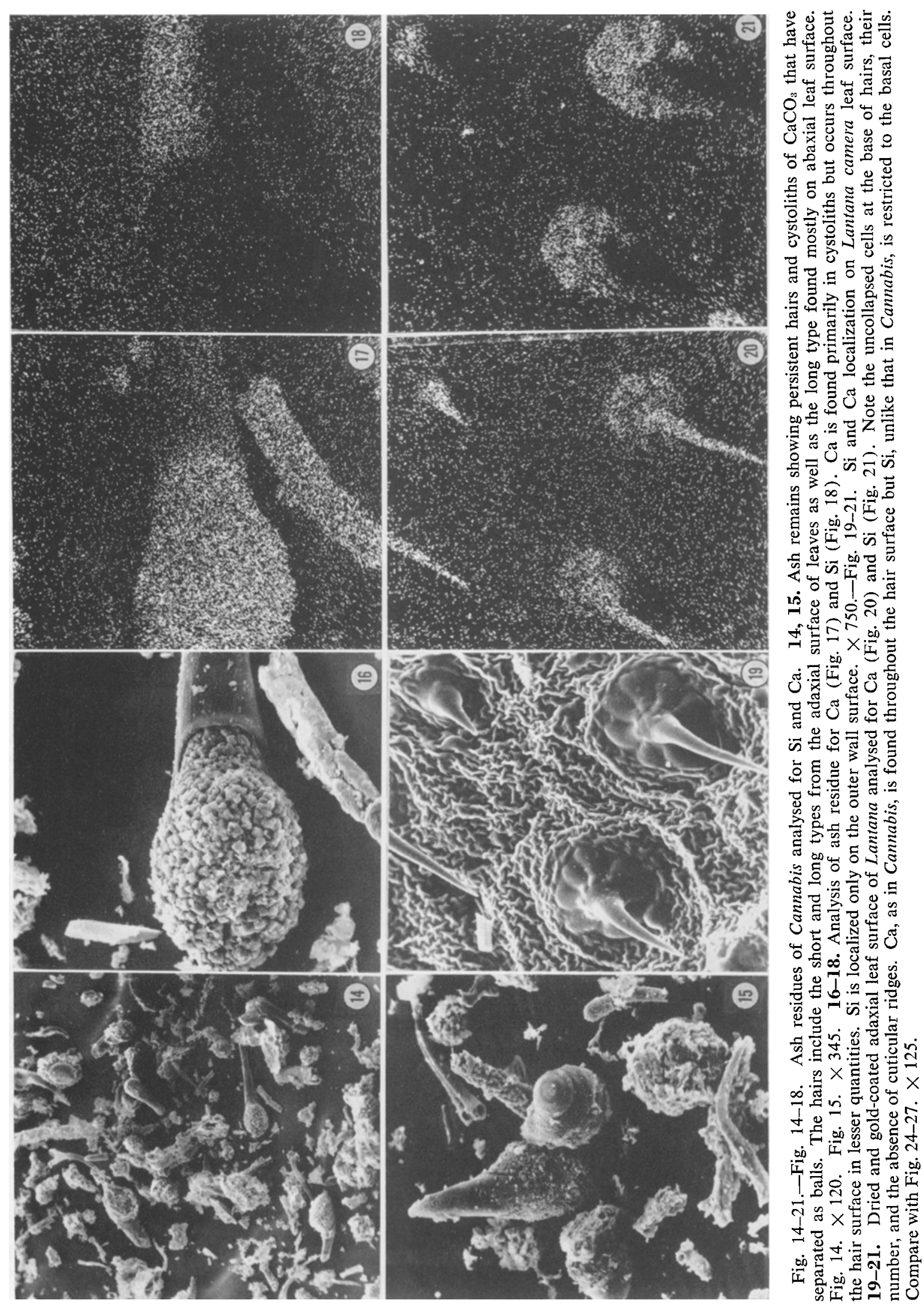



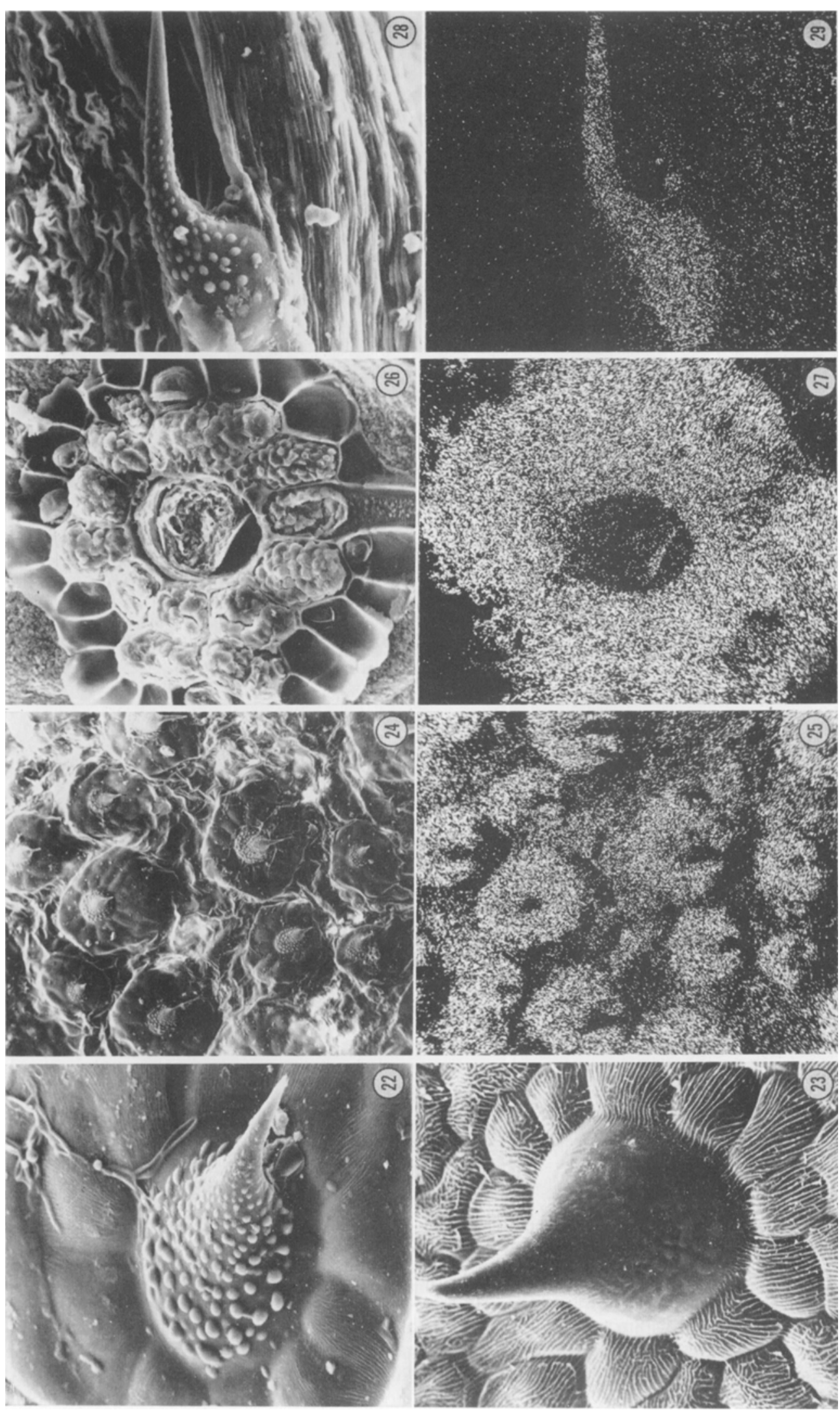

(శ)

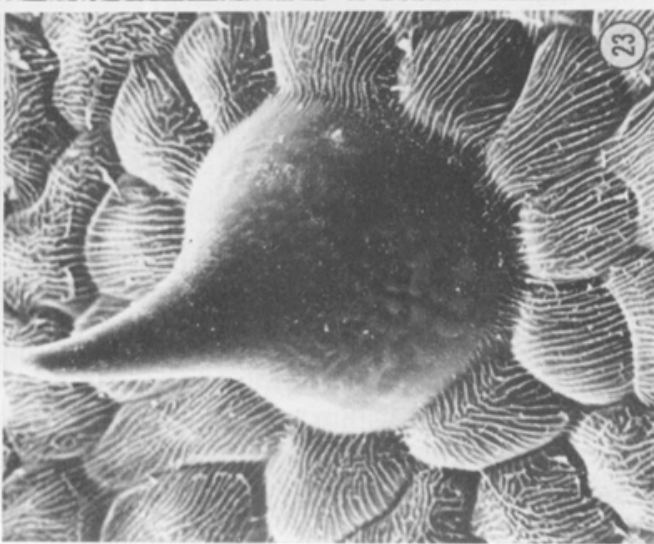

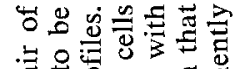

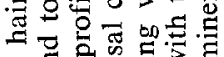

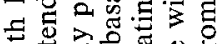

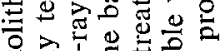
家当安焉

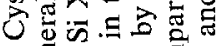

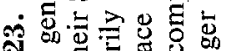

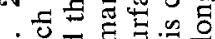

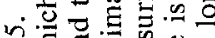
\& 3

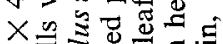
$\times \frac{.}{\overline{0}}=5$

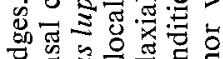

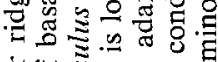

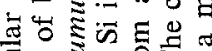

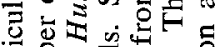

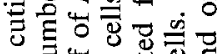

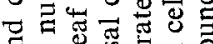

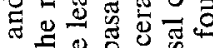

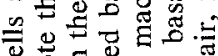

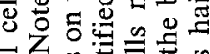
获 I)

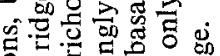

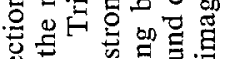
ㅇํㅇ

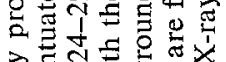

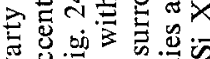

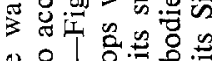

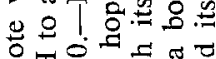

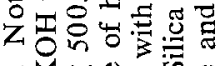
중

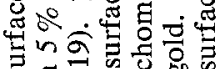

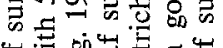

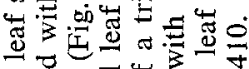

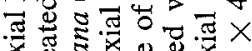

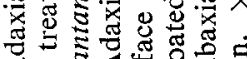

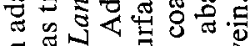
ธี $\Xi$ เ ॐ

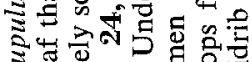

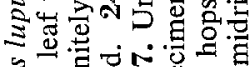

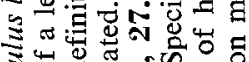
ङ

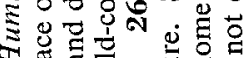
责

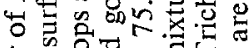
$\because$ क

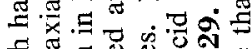

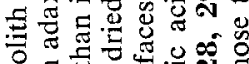
욤

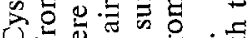
U.

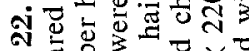
政

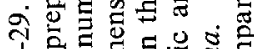

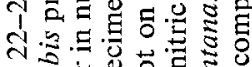
ง

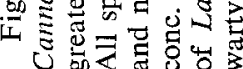




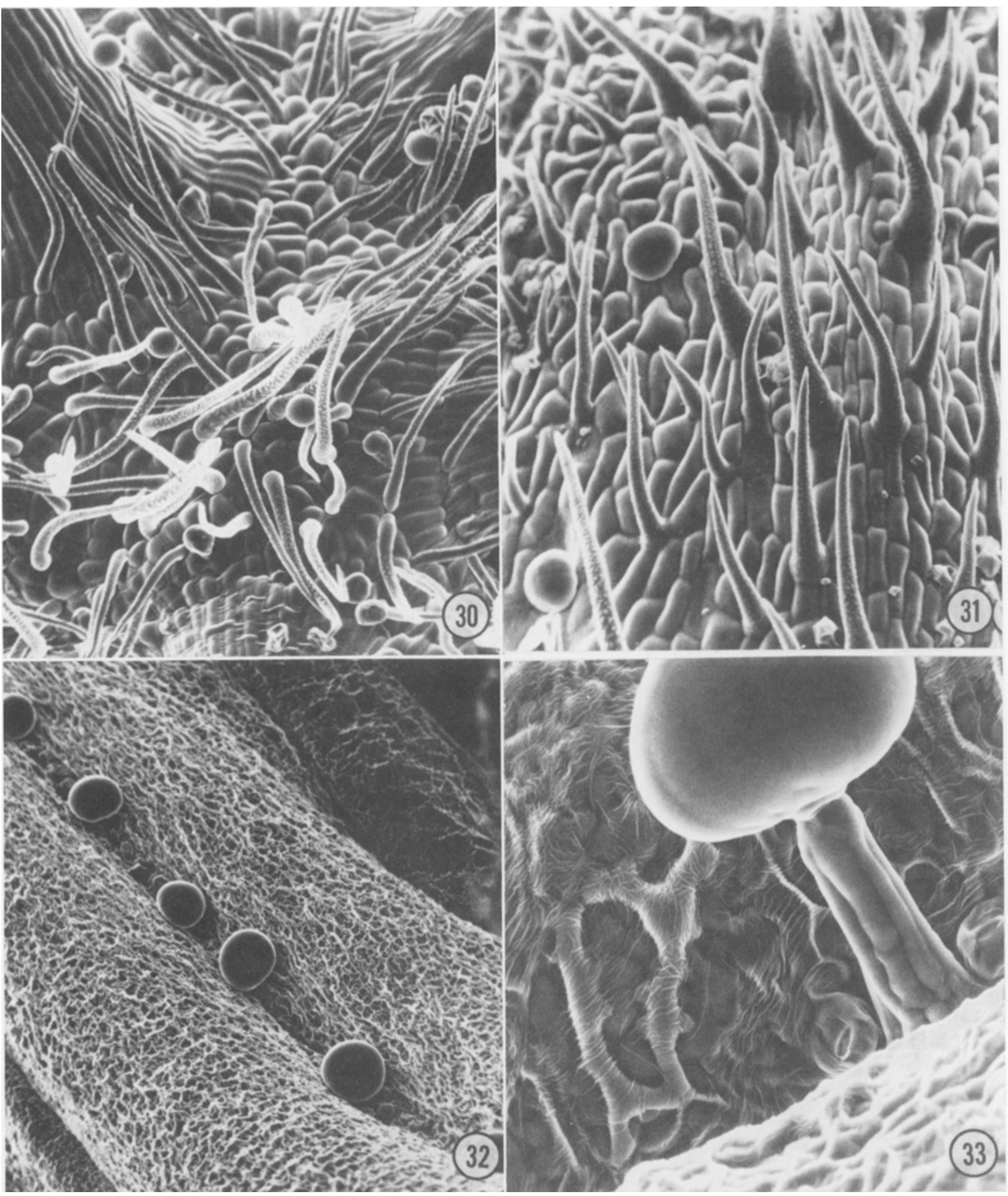

Fig. 30-33. Fresh, live and untreated specimens of male flowers of Cannabis. 30. Central region of a male flower showing the bases of stamens. No pistillode is seen. Glandular and non-glandular hairs are visible. The latter have warty projections. The perfect spheres are pollen grains. $\times 180.31$. Basal region of outer tepal surface. Typical hairs and capitate glands are found, but the epidermal cells lack cuticular ridges. All hairs contain Si. $\times 290$. 32. Surface of anther towards the interior of flower with capitate glands arranged in a row. $\times 100$ 33. Enlarged view of a capitate gland with a long stalk. Also note the stomata and cuticular ridges on epidermis. $\times 400$. 
well-developed hairs and hair initials in early stages of development are also seen on young portions of stems, petiole bases and regions of the leaf between the petiole and the blade (Fig. 2, 34). The leaflet tips, and the small epidermal cells below them, are smooth and lack the characteristic ridges that develop later (Fig. 3). Even though glandular and non-glandular hairs are found at this stage, these regions still lack stomata (Fig. 1). As apical growth of the leaflet ceases, and as stomata begin to differentiate, the epidermal cells enlarge, and the leaflet tips and the adaxial epidermal cells develop the characteristic cuticular ridges (Fig. 3, 23). This pattern is particularly striking on the leaflet tips (Fig. 3).

Two major types of non-glandular hairs cover the shoots of Cannabis. The shorter (about 70$125 \mu \mathrm{m}$ ) and prominent cystolith-containing hairs are generally restricted to the adaxial leaf surfaces (Fig. 7). The longer $(250-370 \mu \mathrm{m})$ and more profuse hairs occur on the abaxial leaf surfaces, stems, petioles and tepals (Fig. 5, 8). All the hairs are pointed towards the tips of the stems or leaves and exhibit varying degrees of warty protuberances. The cystolith hairs on the adaxial leaf surfaces exhibit differences in size and wartiness (Fig. 6, 7). Among the shorter $(70 \mu \mathrm{m})$ ones, some never develop the warty protuberances but they still contain cystoliths (Fig. 10).

$\mathrm{X}$-ray microanalysis reveals that hairs from any part of the plant possess silica $\left(\mathrm{SiO}_{2} \cdot \mathrm{nH}_{2} \mathrm{O}\right)$. Silica is distributed more or less uniformly all over the surface of the trichome (Fig. 8-13). Deposition of calcium as $\mathrm{CaCO}_{3}$ is confined to the enlarged basal portions of the cystolith hairs (Fig. 14-17). The cystoliths are very prominent in hairs on the adaxial leaf surfaces. Some, but not all the hairs from the stem, petiole, and abaxial leaf surfaces also show cystoliths of $\mathrm{CaCO}_{3}$. Because no particular concentration of any element is to be found on the warty protuberances of the trichomes, the protuberances are perhaps due to local depositions of cellulose, cutin or other wall materials.

Remains of marihuana ash reveal the existence of both kinds of hairs as recognizable and distinct entities (Fig. 14-16). The cystoliths of $\mathrm{CaCO}_{3}$ often separate out as balls. X-ray mapping of the ash further confirms the siliceous nature of the hairs and the presence of $\mathrm{Ca}$ in the cystoliths (Fig. 16-18). Some $\mathrm{Ca}$ is probably distributed throughout the inner cavity of the hairs. But the enormous quantities of silica found on the cell walls of the hairs mask the small quantities of $\mathrm{Ca}$ (Fig. 17).

A study of the hairs of Humulus lupulus reveals that some are roughly comparable with the two kinds of hairs found in Cannabis (Fig. 22, 28, $29,42,43)$. However, the following features readily distinguish Cannabis from hops. The abaxial leaf surface of Humulus is totally devoid of hairs except over the midribs and major veins (Fig. 38). The epidermis reveals intricate cuticular ridges which are not found on the abaxial leaf surface in Cannabis (Fig. 5). The stem, inflorescence stalks, petioles and major leaf vein surfaces possess anvil-shaped unicellular hairs in hops (Fig. 39, 40). Hairs of this shape are never found in Cannabis. X-ray microanalysis data also bring out important differences. The hairs on the adaxial leaf surfaces of Humulus are poorly silicified. In contrast, a ring of epidermal cells around the base of each hair is highly silicified (Fig. 24-27). Such basal rings of silicified cells are also found associated with the anvil-shaped hairs (Fig. 40, 41).

Lantana camera is said to possess hairs that are somewhat similar to that of Cannabis. The hairs of this member of Verbenaceae have been described along with those of 90 other plants as being of forensic interest in the identification of illicit marihuana (Nakamura, 1969; Thornton and Nakamura, 1972). Viewed through the SEM, the upper leaf surface of Lantana only superficially resembles that of Cannabis. Lantana leaf epidermal cells lack the cuticular ridges and the hairs do not show warty protuberances (Fig. 19). Lantana has prominent rings of basal cells. These cells are silicified while the hair proper is calcified (Fig. 19-21).

Glandular hairs-Glandular hairs also develop along with the non-glandular hairs. The types of glandular hairs that cover the aerial parts of the pistillate plants, especially those on the bracts, have been described by Hammond and Mahlberg (1973). The latter authors made the first attempt to classify these glands as bulbous, capitate-sessile, and capitate-stalked. Briosi and Tognini (1897) described the bulbous and capitate-sessile glands of Hammond and Mahlberg as almost sessile, and the capitate-stalked glands as stalked. Our studies indicate that the diversity of the glandular hairs has never been fully understood and properly classified. Pistillate plants possess the so-called capitate-stalked glands only in the flowering bracts. Glands that could be described as capitate-stalked also occur on the staminate plants; these are restricted solely to longitudinal rows along the inner surfaces of anthers (Fig. 32, 33). Briosi and Tognini (1897) described the stalks of the capitate-stalked glands of the pistillate plants as primarily derived from epidermal and subepidermal cells at the bases of the glands. These glands possess globular heads and multicellular stalks that can attain a length of about $200 \mu \mathrm{m}$. Some glands have much shorter stalks while others appear to be almost sessile (Fig. 32). The importance of this gradation in stalk length, and the true nature of the multicellular stalk, are described below.

Glands with large globular heads, and apparently without stalks, have been described as 


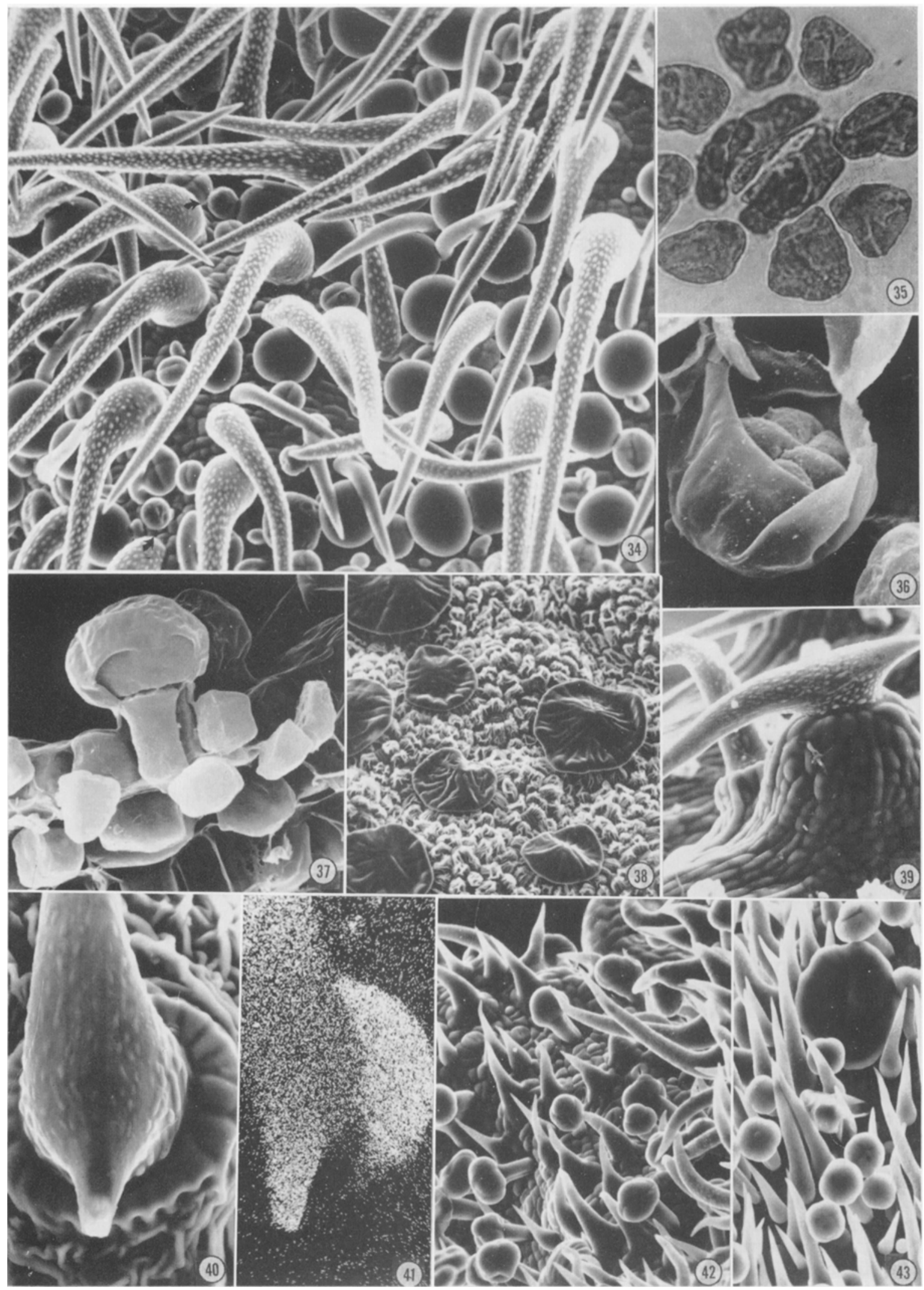


capitate-sessile by Hammond and Mahlberg (1973). These glands are the most abundant type found, and they occur in especially high numbers on the abaxial leaf surfaces, petioles and young stems (Fig. 4-7, 34). The development of these glands from epidermal initials to the fully mature glands with a head of eight cells occurs rapidly during early stages of shoot growth (Fig. $34,56-62)$. These glands are not sessile. Each gland possesses a stalk that is only one cell in length but 2-4 cells thick (Fig. 35). In fact, the previously described capitate-stalked glands are similar in all respects to the so-called capitatesessile glands except for the presence of a massive stalk. The massive stalk, however, is actually a product of the elongation of hypodermal cells below the glands. The cells that make up the heads of the glands of both types form a disc-shaped unit. In early stages this cellular disc is convex and at maturity it may become either a flat or a concave disc (Fig. 36, 58-62). The disc is about $30 \mu \mathrm{m}$ in diam and about $15 \mu \mathrm{m}$ in height. Because of the accumulation of resinous secretions between the outer surface of the disc and the extended cuticular membrane, each gland gives the appearance of a spherical structure (Fig. 34, $45,60)$. Some of the FAA-fixed and criticalpoint dried specimens showed some glands whose outer membranes had ruptured, thus revealing the inner cellular disc (Fig. 36).

Small glandular trichomes (about $15-30 \mu \mathrm{m}$ ) described as bulbous glandular hairs are considered by Hammond and Mahlberg (1973) to be least complex structurally. Our findings indicate that these smaller glands are quite variable (Fig. 46-50). Some have heads made up of single cells and they have stalks that are unicellular. Other glands have four-celled heads with stalks that are two cells thick. The majority of the small glands possess two-celled heads and stalks that are one or two cells long and one or two cells thick (Fig. 51-55). This variability was observed among mature glands. Unlike the capitate glands of sev- eral-celled heads, the smaller glands often possess chloroplasts in the stalk as well as in the head cells (Fig. 51-55). Resinous secretions are found to accumulate within the cells of these smaller glands. With maturity the resin collects beneath the outer membranes of the glands, giving the appearance of nipple or flask-shaped units (Fig. 47, $48,53)$. That these are not artifacts induced by the vacuum in the SEM was evidenced by the observation of such features in fresh specimens examined with a light microscope. Figure 40 shows a region of the outer membrane that is different from the rest of the cuticular membrane. When young leaves are hydrolysed in $1 \mathrm{~N} \mathrm{HCl}$ and squashed between a slide and cover glass, this region is detached and comes off as a contact lens-shaped disc (Fig. 48, 52).

Discussion-Although the description that follows and all but one figure in this article are concerned with the staminate plant, we found the same types of glandular and non-glandular hairs on the pistillate plants also. The exceptions in distributions are to be found only among the male and female flowers themselves.

Both glandular and non-glandular trichomes of Cannabis cover the shoot system of Cannabis from the early seedling stages to maturity. Massively stalked glands (capitate-stalked), however, are restricted to the bracts of the pistillate plants and anthers of the staminate plants. The assumption that resinous glands do not develop until the plant is on the point of flowering is incorrect (Bouquet, 1950). Staminate plants do not possess a restricted number of glandular types as stated by Hammond and Mahlberg (1973). Both the sexes bear similar types of glandular and non-glandular hairs.

Non-glandular trichomes that cover the plants are of two major types. The predominantly cystolith-containing hairs are found on the adaxial surface of the leaves. Differences in size, as well as the existence of warty protuberances on them,

$\leftarrow$

Fig. 34-43.-Fig. 34-37. Cannabis sativa. 34. Details of a region that joins the petioles and leaf blade on the abaxial leaf surface. Well developed trichomes of grandular and non-glandular kinds are found in various stages of development. Two and four-celled trichomes as well as mature capitate glands are seen. Arrows point to bulbous glands. Non-glandular hair initials are also evident. $\times 230.35$. A light micrograph of a squash preparation made from a young leaf. The eight cells that make up the head are seen in the periphery. The four cells in the center constitute the stalk and foot cells. $\times 860$. 36. Fixation and critical point drying have ruptured the outer cuticular membrane revealing the inner disc of head cells that secrete resin. $\times 1125$. 37. Cross-sectional view of a critical-point dried leaf showing the two stalk cells and the head cells of a bulbous-type gland. Fixation has stabilized the protoplasts as solid structures. $\times 2405$.-Fig. 38-43. Humulus lupulus. 38. Abaxial leaf surface of Humulus lupulus. Only large glandular trichomes are found. Epidermal cells have intricate cuticular ridges-a feature not found on the abaxial leaf surface of Cannabis. $\times 155.39$. Anvil-shaped trichome on a raised pedestal on the surface of stem. $\times 175,40,41$. Secondary electron image and an X-ray image for Si. This anvil-shaped trichome from the stem surface possesses a ring of silicified cells similar to those on the adaxial leaf surface. Tilting of the specimen has cut off the $X$-ray image from some parts around the trichome. $\times 345$. 42, 43. Large lupulin gland and several bulbous type glands found on the outer surfaces of flowering bracts. These two types of glands recall the capitate and bulbous glands of Cannabis. $\times 220$. 


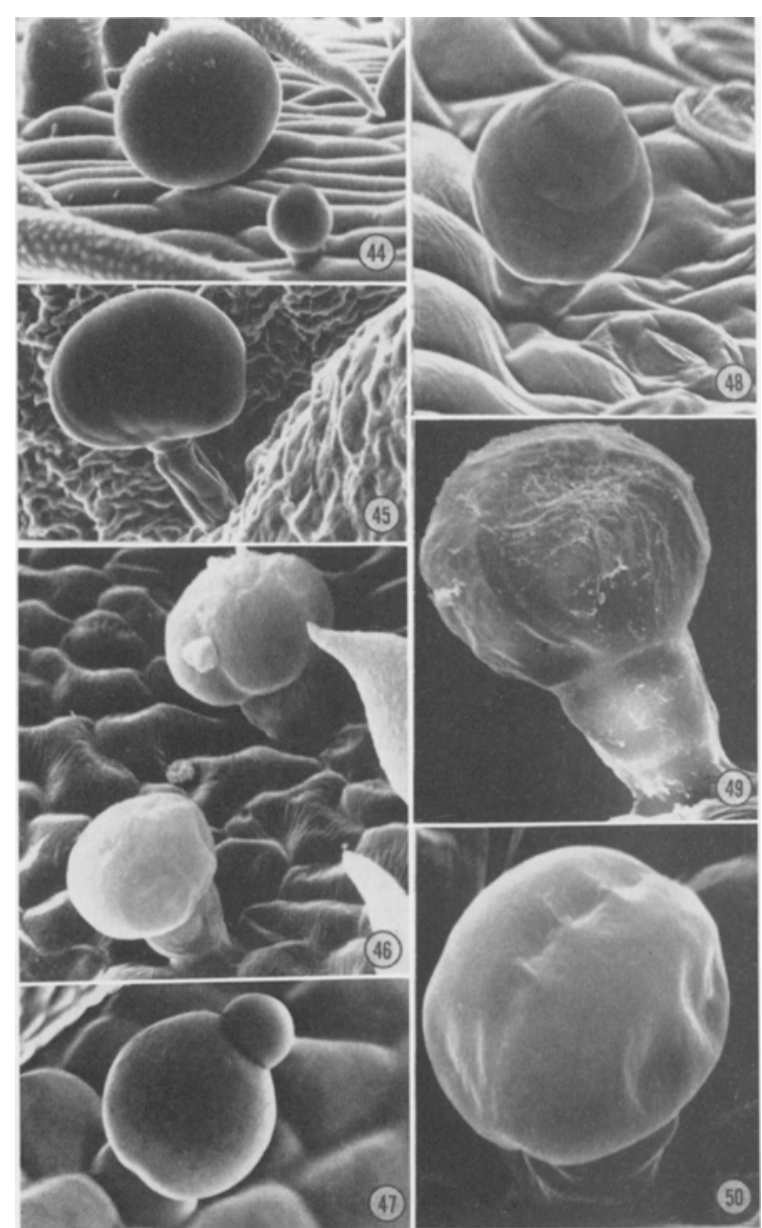

Fig. 44-50. Different types of glandular hairs of Cannabis. All figures except Fig. 46, 49 and 50 were prepared from fresh, live specimens without any treatment. Fig. 46, 49 and 50 are from critical-point dried preparations. 44. Capitate and bulbous glands over a vein on the abaxial leaf surface. Both glands are stalked even though the stalk of the capitate gland is not visible in this view. The larger size of the capitate gland is mainly due to the accumulated resin under the cuticle. $\times 340$. 45. Capitate gland with a prominent pseudostalk on the surface of the anther wall that faces the center of the flower. $\times 240$. 46. Two bulbous glands on the adaxial leaf surface. Both have stalks made up of two cells each but the lower one has a head made of two cells and the upper one has a four-celled head. $\times 1010$. 47. A bulbous gland from a young adaxial leaf surface. The tip over the head is resin-filled cuticle. $\times 1125$. 48. Bulbous gland from abaxial leaf surface. The stalk and head are made up of two cells each. The tip of the gland possesses a small disc shaped region below which resin accumulates in the extended membrane. $\times 1125$. 49. Bulbous gland from petiole surface. The head is made of a single cell, and the stalk of two cells, one above another. $\times 1690$. 50. Bulbous gland from abaxial leaf surface with the head and stalk each made of two cells. $\times 2250$.

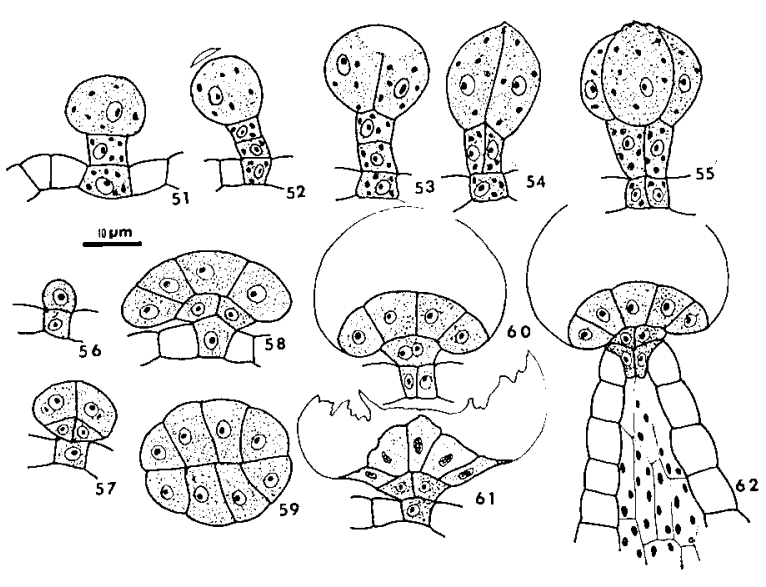

Fig. 51-62. Various gland types of Cannabis drawn to scale.-Fig. 51-55. Bulbous glands. 51. Gland with one cell each for head, stalk and foot. 52. One-celled foot, stalk with two cells one above another and head with one cell. The disc above represents the structure that can be detached from the tip of some glands. $\mathbf{5 3}$. Similar to gland in Fig. 52 but with two-celled head. Resin accumulated within the cell. 54. Foot has one cell but the stalk is two cells thick. Head has two cells. 55. Foot and stalk, each has two cells and the head is of four cells.-Fig. 56-62. Many celled, capitate glands. 56. Initiation of capitate gland. 57. Foot with one cell, stalk with two cells, and head in the four cell stage. 58, 59. Lateral and surface views of fully developed gland before secretory activity. 60. Gland with extended membrane within which resin accumulates. 61. Gland after the membrane has ruptured and the secretory activity has declined. 62. This gland from a female bract shows the hypodermal and subepidermal nature of the massive stalk. The gland proper still has the same features that are found in such glands on leaves and stems.

help to distinguish two kinds of cystolith hairs (Fig. 2, 6, 7, 10). About 15-20 epidermal cells form a circle at the base of the cystolith hairs (Fig. 10, 23). In Humulus, such cells are filled with silica bodies (Fig. 22, 24-27). A detailed study of the non-glandular hairs among all the different cultivars of Cannabis might reveal features that may be of help in solving taxonomic relationships of this genus.

The need for the identification of marihuana from illicit samples has led to a study of distinguishing features that remain identifiable even in marihuana ash (De Forest et al., 1974). This has resulted in valuable comparative studies involving some 600 species of plants that are known to possess cystolith hairs (Nakamura, 1969; Thornton and Nakamura, 1972; Nakamura and Thornton, 1973). Because the scanning electron microscope is finding increasing use in criminalistics, we have furthered its use in the identification of marihuana by coupling the SEM to an Xray detector analyser system (see Methods). 
Where chemical and light microscopic tests fail, SEM and X-ray analysis may result in definitive identification of marihuana fragments even in ash remains (Fig. 14, 18). The characteristic silica and calcium profiles readily distinguish Cannabis from Humulus and Lantana, two plants whose hairs are known to resemble the Cannabis hairs (Fig. 14-18). Differences that exist in calcium and silica X-ray profiles between Cannabis and Humulus clearly distinguish these two genera of Cannabaceae. A preliminary examination shows that members of Moraceae such as Ficus and Morus exhibit similar distinguishing patterns in silicification and calcification. X-ray microanalysis with the SEM thus promises to be a valuable tool in plant systematics.

The silicified trichomes, especially the cystolith hairs, resemble curved, pointed glass needles. Marihuana is often consumed orally in several kinds of preparations. Such preparations for oral consumption reach their greatest diversity in India (Chopra and Chopra, 1957). Is it possible that some of the adverse effects of oral consumption of marihuana, especially on the gastrointestinal system, may be due to irritations caused by the siliceous trichomes?

Glandular hairs of different kinds have been described under different names by the previous workers (Briosi and Tognini, 1894, 1897; Bouquet, 1950; Jackson and Snowdon, 1968; Hammond and Mahlberg, 1973). Some have described only the massively stalked capitate glands or apparently stalkless capitate glands. Hammond and Mahlberg (1973) classify the glandular hairs as capitate-stalked, capitate-sessile and bulbous. Our investigations show that better terminology is needed to describe these glands. For example, the so-called capitate-sessile glands are in fact not sessile; they possess stalks that are one cell in height and generally two cells in thickness. Again, the so-called capitate-stalked glands do in fact possess only as many true stalk cells as the so-called capitate-sessile glands. The massive stalk or pedicel of these glands that occur on the bracts of the pistillate plants appear to be derived from the epidermal and hypodermal cells below the glands (Briosi and Tognini, 1897). These could then be only pseudo-stalks. Also, some authors have implied that the various types of glands are but different expressions of one type (Bouquet, 1950; Mohan Ram and Nath, 1964). Briosi and Tognini (1897) classified the glands as almost sessile and stalked and included all glands except the ones produced on the flowering bracts in the first category.

We have avoided proposing new terms to describe the different types of glands because of a lack of detailed ontogenetic studies. Instead, we use the existing terminologies rather loosely to describe our observation. Our studies indicate that there are two major groups of glands. The first group (capitate) consists of glands whose heads are made up mostly of 8 cells (Fig. 35, 36, $45,58-62$ ). The head is supported by a stalk that is one cell in height and two to four cells in thickness (Fig. 58, 60). The stalk is in turn supported by a foot which is one or two cells wide and is level with the epidermal surface (Fig. 35, 5662 ). Glands of this category seem to be stimulated, during anthesis, to produce massive stalks in flowering bracts of female flowers and anthers of male flowers (Fig. 33, 45, 62). These massive stalks, whether on bracts of pistillate plants or on anthers of staminate plants, are hypodermal and epidermal in origin and are best described as pusedo-stalks.

The second group of glands (bulbous) is a collection of different types of glands (Fig. 37, 46$50,51-55)$. They are all generally stalked. Unlike the capitate glands, the bulbous glands possess chloroplasts in their stalks as well as in their heads. The head is made up of one, two or four cells (Fig. 37, 51-55). The stalks of these glands are either one or two cells in height and when one cell high, the stalk can be one or two cells thick (Fig. 46-49, 51-55). A foot made of one or two cells lie level with the epidermis and the cells have staining properties different from the ordinary epidermal cells (Fig. 51-55). A distinction between the stalk cell and the foot cell is not always possible (Fig. 37). Some of these glands also possess unique disc-shaped regions on the cell wall, near the apex of the glands (Fig. 48, 52). The chemical nature, formation and function of these discs are not known.

The bulbous glands appear to be smaller than the capitate glands (Fig. 44). This is due to the fact that the cuticular membranes of the capitate glands extend considerably to accommodate the resinous secretions and thus appear three to four times larger than the bulbous glands (Fig. 36, 44). The actual sizes of the heads of both types of glands are quite comparable (Fig. 53-62). The bulbous glands accumulate only small quantities of resin. Judging from the accumulation of resin and the resulting shapes, the bulbous glands seem to be most active in their secreting activities during early stages of shoot development.

It is generally assumed that the inebriating properties of marihuana is due to the secretions of the glandular hairs. Direct evidence for this is meagre (Hammond and Mahlberg, 1973). Fujita et al. (1967) presented gas-liquid chromatographic evidence for the presence of tetrahydrocannabinol inside the cellular discs of the capitate glands. Cannabis preparations are known to contain about 20 different related compounds, collectively called cannabinoids (Mechoulam, 1970). Cannabidiolic acid is said to be the precursor from which cannabidiol, tetrahydrocannabinol and cannabinol are derived, in that order. The biologically active isomers of tetrahydrocannabinols 
themselves are said to be produced only during drying and storage of plant material, or during extraction, or smoking (Schultes and Hofmann, 1973). Recent studies have demonstrated that the staminate plants possess as much and as many cannabinoids per unit fresh weight as the pistillate plants (Agurell, 1970; Fetterman et al., 1971). This correlates well with our finding of as many different types of glandular hairs in staminate plants as in pistillate plants.

The precise location of the various types of cannabinoids in the different types of glands calls for the use of sensitive histochemical reagents and techniques. Reagents used in Beam's test, Ghamrawy's test, Duquenois and Negm's reaction and its modifications should be tested for their efficiency and specificity as histochemical reagents (Duquenois, 1950; Thornton and Nakamura, 1972). Variations in the activity of the different glands during different growth stages also need to be studied to understand the pharmacological activities of preparations from various stages of plant growth.

Humulus is the only other genus in the family Cannabaceae. Humulus lupulus (hops) is of economic importance because of the lupulin glands found on the flowering bracts that are used in the brewing of beer. These glands superficially resemble the capitate glands of Cannabis and are distributed not only over the flowering bracts, but also on the abaxial leaf surfaces (Fig. 38, 43). A striking feature in hops is the profuse occurrence of bulbous-type glands over the flowering bracts (Fig. 42, 43). These glands recall the bulbous glands of Cannabis that have four-celled heads (Fig. 46, 55). A better understanding of the properties of all the different cannabinoids from Cannabis and of the various secretions from the different glands of Humulus may throw light on the inebriating properties and popularity of beer. At present, no component of hops is shown to possess properties similar to tetrahydrocannabinol of marihuana.

The genus Cannabis itself is generally assumed to be monotypic (Small, 1975). Schultes et al. (1974) contend that there are three species, namely, $C$. sativa, $C$. indica and $C$. ruderalis. Some of the discrepancies in the accounts of the morphology and anatomy, especially of the trichomes, and of the pharmacological activity of different cultivars from different parts of the world, may be due to the failure to distinguish the true taxonomic nature of the plant under investigation. Detailed study of the trichomes and their ontogeny as well as the histochemistry and ultrastructure of Cannabis plants, especially of the presumably wild populations, will throw further light on the taxonomy of this genus.

There is much interest in this ancient domesticated plant of current controversies. Yet, very little is known about it scientifically. Little won- der that it is called a "deceptive weed," "a signal of misunderstanding" and "an example of taxonomic neglect."

\section{LITERATURE CITED}

Agurell, S. 1970. Constituents of male and female Cannabis, p. 57-59. In C. R. B. Joyce and S. H. Curry [ed.], The botany and chemistry of Cannabis. Churchill, London.

Asahina, H., M. Ono, K. Takahashi, and Y. Ono. 1967. Identification of Cannabis resin. Bull. Natl. Inst. Hyg. Sci. Tokyo 85: 123-125.

Ballard, C. W., and D. Phar. 1915. Notes on the histology of an American Cannabis. J. Am. Pharm. Assoc. 4: 1299-1303.

BouQuet, R. J. 1950. Cannabis. Bull. Narcotics 2(4): 14-30.

BradFord, L. W., AND J. Devaney. 1970. Scanning electron microscopy applications in criminalistics. J. Forensic Sci. 15: 110-119.

Briosi, G., AND F. Tognini. 1894. Intorno alla anatomia della canapa (Cannabis sativa L.). Parte prima: Organi sessuali. Atti Ist. Bot. Pavia, Ser. 2. 3: 91-209.

, AND . 1897. Intorno alla anatomia della canapa (Cannabis sativa L.). Parte seconda: Organi vegetativi. Atti Ist. Bot. Pavia, Ser. 2. 4: $155-329$.

Chopra, I. C., and R. N. Chopra. 1957. The use of of the Cannabis drugs in India. Bull. Narcotics 9 (1): 4-29.

De Forest, P. R., C. V. Morton, and R. A. HenderSON. 1974. Microscopic morphology of marijuana ash. J. Forensic Sci. 19: 372-378.

Devaney, J. R., and L. W. Bradford. 1971. Applications of scanning electron microscopy to forensic science at Jet Propulsion Laboratory. 1969-1970, pt. 2, p. 561-568. In O. Johari and I. Corvin [ed.], Scanning electron microscope symposium, Scanning electron microscopy proceedings. IIT Research Institute, Chicago.

DuQuenoIs, P. 1950. Chemical and physiological identification of Indian hemp. Bull. Narcotics 2 (3) : 30-33.

Fetterman, P. S., D. S. Keith, C. W. Waller, O. GuerRERo, N. J. Doorenbos, AND M. W. Quimby. 1971. Mississippi-grown Cannabis sativa L.: Preliminary observation on chemical definition of phenotype and variations in tetrahydrocannabinol content versus age, sex, and plant part. J. Pharm. Sci. 60: 1246-1249.

Fujita, M., S. Hiroko, E. Kuriyama, M. Shigehiro, AND M. AKasu. 1967. Studies on Cannabis. II. Examination of the narcotic and its related components in hemps, crude drugs, and plant organs by gas-liquid chromatography and thin-layer chromatography. Annu. Rep. Tokyo Coll. Pharm. 17: 238-242.

Hammond, C. T., and P. G. Mahlberg. 1973. Morphology of glandular hairs of Cannabis sativa from scanning electron microscopy. Amer. J. Bot. 60: 524-528.

JACKSON, B. P., AND D. W. SNowdon. 1968. In Powdered vegetable drugs, p. 58-65. American Elsevier.

Mechoulam, R. 1970. Marihuana chemistry. Science 168: 1159-1166.

Mitosinka, G. T., J. I. Thornton, and T. L. Hayes. 
1972. The examination of cystolith hairs of Cannabis and other plants by means of the scanning electron microscope. J. Forensic Sci. Soc. 12: 521529.

Mohan Ram, H. Y., and R. Nath. 1964. The morphology and embryology of Cannabis sativa Linn. Phytomorphology 14: 414-429.

NAKAMURA, G. R. 1969 . Forensic aspects of eystolith hairs of Cannabis and other plants. J. Assoc. Off. Anal. Chem. 52: 5-16.

- AND J. I. THORnTon. 1973. The forensic identification of marijuana-some questions and answers. J. Pol. Sci. Admin. 1: 102-105.

Nordal, A. 1970. Microscopic detection of Cannabis in the pure state and in semi-combusted residues, $\mathrm{p}$. 61-68. In C. R. B. Joyce and S. H. Curry [ed.], The botany and chemistry of Cannabis. Churchill, London.

Schultes, R. E. 1970. Random thoughts and queries on the botany of Cannabis, p. 11-38. In C. R. B. Joyce and S. H. Curry [ed.], The botany and chemistry of Cannabis. Churchill, London.

-, AND A. Hofmann. 1973. The botany and chemistry of hallucinogens. Charles C. Thomas Publisher, Springfield, Illinois.

W. M. Klein, T. Plowman, and T. E. LockwooD. 1974. Cannabis: an example of taxonomic neglect. Bot. Mus. Leafl., Harvard University $23: 337-367$

Shimomura, H., M. Shigehiro, E. Kuriyama, and M. FuJita. 1967. Studies on Cannabis. I. Microscopical characters of their internal morphology and spodogram. Annu. Rep. Tokyo Coll. Pharm. 17: $232-237$.

Siegesmund, K. A., ANd G. M. Hunter. 1971. Scanning electron microscopy of selected crime laboratory specimens, pt. 2, p. 577-584. In O. Johari and $\mathrm{I}$. Corvin [ed.], Scanning electron microscope symposium, Scanning electron microscopy proceedings. IIT Research Institute, Chicago.

Small, E. 1975. American law and the species problem in Cannabis: Science and semantics. Bull. Narcotics 27(3): $1-20$.

Thorton, J. I., and G. R. Nakamura. 1972. The identification of marijuana. J. Forensic Sci. Soc. 12: $461-505$ 